\title{
Kisgyermeket nevelő szülők támogatásának hazai és nemzetközi lehetőségei, személyes és távsegítő formái - szakirodalmi áttekintés
}

\author{
Gyöngy Kinga
}

Eötvös Loránd Tudományegyetem Tanitó- és Óvóképző Kar Neveléstudományi Tanszék

\begin{abstract}
Absztrakt
A szülősegítés évszázados múltra tekint vissza, melynek különböző formái vannak a nevelési tanácsoktól a különböző szülőtréningekig. Szakirodalmi áttekintésünkben különös hangsúlyt fektetünk a három éven aluli kisgyermekeket nevelő szülők támogatásának lehetőségeire. Áttekintjük a szülők támogatásának változatait, majd a távsegítés hazai és nemzetközi lehetőségeit, ezek formáit és hatékonyságát mutatjuk be. Az interneten keresztüli segítségnyújtás az elmúlt évtizedek egyik vívmánya, melynek fontosságára a Covid19-járvány miatti lezárások kényszerüsége is rámutatott. Írásunk végén a lehetséges távsegítő formák egy speciális formájáról, a szülőknek szóló tömeges nyílt online kurzusokról szólunk.
\end{abstract}

Kulcsszavak: szülősegítés, digitális saját ütemben végzett szülőtréning, MOOC

\section{Bevezetés}

2020 szeptemberében az ELTETÓK oktatói tömeges nyílt online kurzust (MOOC-ot) tartottak érdeklődő szülőknek Túlélőkészlet kisgyermekes szülőknek címmel. A kurzus fejlesztése és kiértékelése közben több hullámban tájékozódtunk a Magyarországon és külföldön elérhető szülősegítő formákról. Tapasztalataink szerint a szülőket nagyon sok különböző formájú, minőségű és célú professzionális és amatőr szolgáltatás célozza meg. Írásunkban ezek rendszerezésére és kritikai bemutatására vállalkozunk, különös figyelmet fordítva a három év alatti kisgyermeket nevelő szülők célcsoportjára.

A szülők segítése sokféleképp történhet, a támogatást igénybe vevő szülő igényeitől és a támogatást nyújtó lehetőségeitől függően. A szülői nevelés támogatásának, szülők pszichoedukációjának célja a gyermekek jóllétének előmozdítása, a szülő-gyermek kapcsolat erősítése (Cs. Ferenczi, 2019).

Különbséget kell tennünk a prevenciós és az intervenciós jellegű szülősegítő formák közt. A prevenciós jellegű szülősegítés a gyermek születését vagy 
a problémák kialakulását megelőzően nyújt ismereteket, támogatást, hogy a gyermeki pszichopatológia vagy a szülö-gyermek kapcsolat terheltsége ne alakuljon ki. Az intervenció a már kialakult problémák orvoslását tűzi ki célul.

A megvalósítás tekintetében az univerzálisan elérhetőtől a specifikus igényekre válaszoló szülősegítésig többféle formát találunk. A szülők támogatásának vannak rendszerszintü, általánosan elérhető, vagy akár kötelező elemei (1.), klinikai gyakorlatban megvalósuló, célzott problémák esetén igénybe vehető formái, akár társadalombiztosítási finanszírozással (2.), valamint bizonyos célcsoportok számára kialakított formái (3.), melyek költségeit többnyire a résztvevők állják vagy pályázati, önkormányzati, illetve alapítványi forrásból támogatottak.

Eredetileg a legtöbb szülősegítő forma jelenléti, személyes találkozáson alapuló ellátás volt, mára azonban mind az elérhetőség megkönnyítése érdekében, mind a Covid19-járvány okozta 2020-2021-es lezárások miatt több szolgáltatás az online térbe költözött. Különbséget kell tennünk aközött, amikor az online szolgáltatás csupán a jelenléti szolgáltatás időszakos korlátozása miatti kényszerủ és alacsonyabbrendű megoldást jelent, melynek célja a szolgáltatás elérhetőségének fenntartása, valamint aközött a megoldás között, amikor a szülősegítést az online tér lehetőségeire szabva adaptálják, és a jelenléti szolgáltatással megegyező hatékonysággal számolva hosszútávú üzemeltetésre rendezkednek be.

\section{Rendszerszintü szülösegítés Magyarországon}

Az állami támogatást élvező, rendszerszinten működő szülősegítő formák esetében a világon mindenütt felmerül a beruházás megtérülésének kérdése. A szülősegítés eredményességét vizsgáló publikációk többnyire a gyermekek iskolai- és életben való sikerességét, patológiamentességét tekintik a korai szülőtámogató programok kimeneti változójaként. Közgazdasági értelemben akkor térül meg a prevenciós vagy intervenciós programokba fektetett pénz és energia, ha hosszú távon a gyermek jóllétéhez, egészséges fejlődéséhez járul hozzá (Lannert, 2015). Szélesebb értelemben nemcsak az egyes gyermekek egészséges fejlődése utal a koragyermekkori évekbe való beruházás megtérülésére, hanem a haszon „a nők gyermek- és munkavállalási hajlandóságának növekedésében, a családok stabilitásának megőrzésében, a gyerekek későbbi tanulmányi, munkaerőpiaci és társadalmi sikerességében, valamint a speciális ellátások szükségességének és a társadalmi devianciák csökkenésében mérhető". (Danis, 2020a, p. 24). Ezek a változások azonban csak közép- és hosszútávon jelentkeznek a jól megtervezett rendszerszintü ellátások folyamatos elérhetősége mellett (Danis, 2020a).

A védőnői szolgálat Európában egyedülállónak tekinthető (Szőllősi et al., 2020): az egészségügyi alapellátás részeként a gyermekorvosi ellátás mellett működik. Âllamilag finanszírozott, mindenki számára elérhető és kötelező családsegítő szolgáltatás, mely elsősorban egészségügyi célokért (preven- 
ció, oltásfegyelem megtartása, fejlődési lemaradások, elakadások mielőbbi felismerése), illetve a gyermekek és anyák védelméért dolgozik. A védőnők a várandósgondozás és a kisgyermekes évek során a családlátogatások és a védőnői státuszvizsgálatok keretében tanácsadással támogatják a szülőket (Kereki \& Major, 2014). A védőnői ellátás 2012-től egy EU által finanszírozott projekt ${ }^{1}$ keretében jelentős fejlesztésen ment át. A státuszvizsgálatokhoz elkészült egy gyermekek fejlettségét mérő kérdőív, amelyet a szülők segítségével töltenek ki a védőnők, ezáltal pontosabb képet alkotva a gyermek fejlettségéről, lehetővé téve az esetleges fejlődési lemaradások mihamarabb észlelését, és erősítve a szülő és a szakember között kialakuló partneri kapcsolatot (Deutsch et al., 2019). A fejlesztés keretében született meg a Koragyermekkor portál ${ }^{2}$ is, melynek célja a szülők és szakemberek informálása.

A szülősegítést érdemes megkülönböztetni a gyermekeket közvetlenül célzó fejlesztő foglalkozásoktól. Magyarországon az általánosan kötelező, ingyenes óvodáztatás tipikusan a gyermekek fejlesztését célzó beavatkozás (Paszkoszné Kulcsár, 2013). A Biztos Kezdet program ezzel szemben olyan törvényi szabályozással ${ }^{3}$ rendelkező ellátási forma, mely a hátrányos helyzetü szülők megsegítését is célozza (Biztos Kezdet, 2021). A Biztos Kezdet programban a szülői készségek fejlesztését, a gyermeki fejlődésről szóló ismeretek bővítését, a gyermekkel kapcsolatos pozitív szemlélet erősítését célozzák meg a Gyerekházak dolgozói és az általuk szervezett foglalkozások, melyeken a szülő és napközbeni ellátásba még nem járó gyermeke közösen vesznek részt (Sörös, 2016). Amikor a gyermek már bekerül a napközbeni ellátásba, akkor a szülők támogatását a pedagógusok veszik át, például a három éven aluli gyermekek szülei számára a bölcsődék lehetőséget biztosítanak szülőcsoportos beszélgetésekre, illetve a gyermekkel, gyermekneveléssel kapcsolatban tanácsadást is tudnak nyújtani, ha a szülő igényli.

\section{Koragyermekkori problémák kezelése a szülök bevonásával}

A gyermeknél jelentkező problémák sokszínűek, ugyanakkor alapvetően három fö kategóriába sorolhatóak (Danis, 2020a).

1. A biológiai hátrányból eredeztethető fejlődési lemaradás, sajátos nevelési igény korai fejlesztéssel, gyógypedagógusi, gyógytornászi, fejlesztőpedagógusi segítségnyújtással csökkenthető.

2. A szociális helyzet miatti hátrány koragyermekkori inklúziós programokkal (például Biztos Kezdet programmal) kompenzálható.

3. A pszichés jóllét problémái koragyermekkori mentálhigiénés ellátásokkal, szülőtréinggel minimalizálhatóak.

Ezek a problématípusok keverten is előfordulhatnak, halmozódhatnak, emiatt az univerzális ellátás helyett egyéni „kliens utak” (Kereki, 2015) kidol-

\footnotetext{
${ }^{1}$ TÁMOP-6.1.4/12/1-2012-0001 Koragyermekkori (0-7 év) program.

${ }^{2}$ koragyermekkor.hu

${ }^{3}$ Gyvt. 38.\$
} 
gozására van szükség. Ezen problémák kezelését hagyományosan szakemberek végezték a gyermekekkel, mára azonban a gyermekkel való kizárólagos foglalkozást felváltotta a szülők bevonásával végzett intervenció. (lásd 1. ábra) A szülői kompetenciák erősítése és a szülőség (parenting), nevelő hatást gyakorol a gyermek fejlődésére, miközben a gyermek is hatást gyakorol szüleire, a szülő-gyermek egymásra hatás időbeli előrehaladása révén tranzakciós folyamatok játszódnak le a családokban, melyek kedvező vagy kedvezőtlen irányba vihetik a családi interakciókat, illetve a gyermek fejlődését.

\section{1. ábra}

A kisgyermekkori intervenciók hatásmechanizmusai. (Forrás: Danis, 2020a, p. 29).

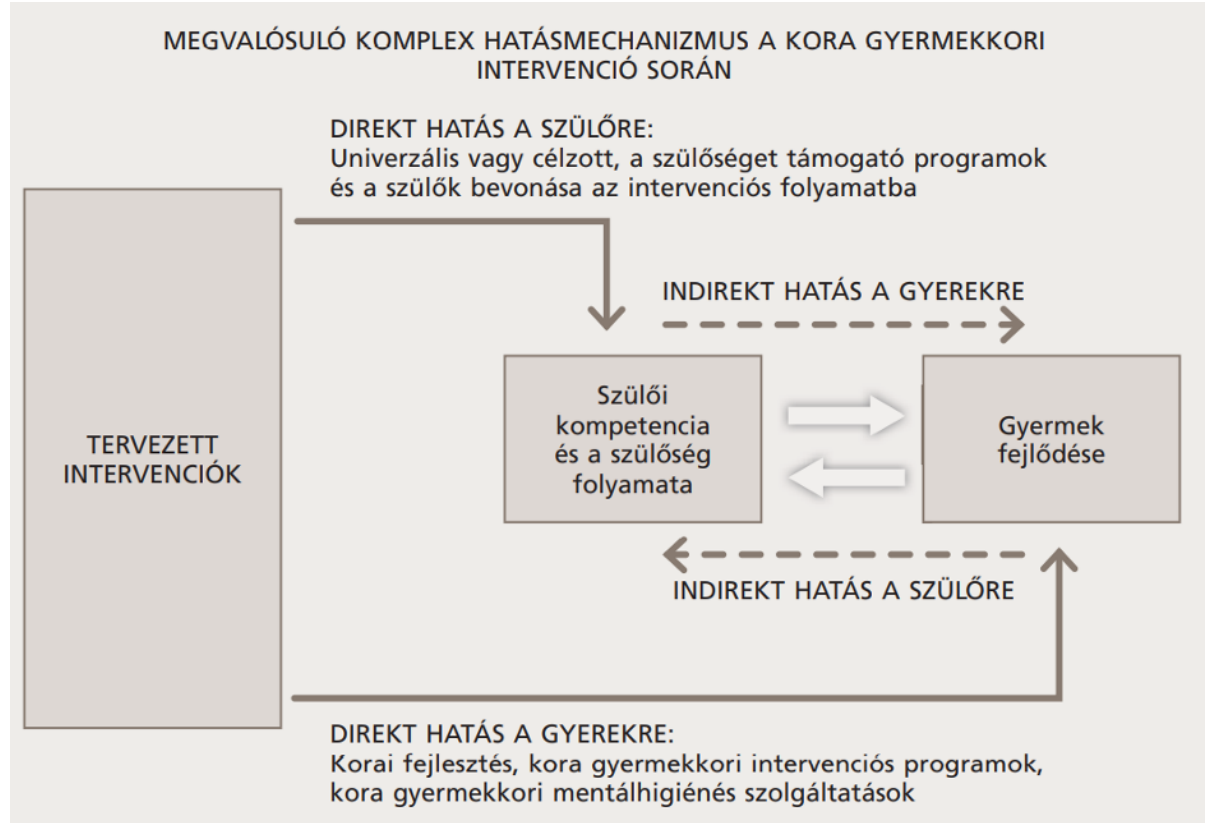

A korai fejlesztés hálózatának magyarországi kiépítettsége több évtizedes múltra tekint vissza, törvényileg szabályozott, a különböző szakmák együttmüködésével megvalósuló folyamat, mely az elmúlt évtizedben kiemelt figyelmet kapott EU-finanszírozott projektek keretében (Danis, 2020a). A szociális hátránykompenzáció érdekében úgyszintén történtek állami szintü erőfeszítések, Ide sorolható, a már említett Biztos Kezdet hálózat fejlesztése.

A koragyermekkori mentálhigiénés segítségnyújtás még a hálózatosodás előtt áll Magyarországon. A koragyermekkori nevelési problémákkal kapcsolatos segítségnyújtás a szülőt célozza meg. Ezek közé tartozik a szülőcsecsemő konzultáció (Németh \& Hédervári-Heller, 2020; Hámori, 2020), illetve a szülőknek szóló pszichoterápia (Frigyes \& Molnár, 2020). Említésre méltó a dokumentált hatékonyságú, pszichoterápiás módszereket használó 
pár- és családterápia (Shadish et al., 1995; Carr, 2009) vagy a segítő kamerával dolgozó (Magyar Videotréning Egyesület által nyújtott) családi videotréning hatásvizsgálatai (például Rackett \& Macdonald, 2014; Hoffenkamp et al., 2015).

\section{Bizonyítottan hatékony szülősegítés}

A szülősegítésnek van egy olyan ága, mely a szülők tréningjét csoportos formában valósítja meg, nemzetközi gyakorlatban kialakított protokollok alapján müködik, és a „bizonyítottan hatékony” jelző megszerzésére törekszik. „Hazánkban is lehetőségünk lenne a már működő, ígéretesnek tűnő gyakorlatok, modellprogramok tudományos nyomon követésére, szisztematikus eredményesség- és hatékonyságvizsgálatára, amely a tapasztalati úton nyert hasznosság érzése mellett a bizonyítékokon alapuló (evidence-based) működésmód biztonságát is nyújtaná." (Danis, 2020b, p. 74). Többnyire az intervenciós jellegű szülőtréningek azok, melyek esetében a gyermeki problémák csökkenésében jól mérhető a szülőtréning hatásfoka.

\section{Gyermeki problémás viselkedésre kidolgozott szülötréningek hatásvizsgálatai}

A gyermeki viselkedésbeli problémák jelentkezése a szülö-csecsemő konzultációval kezelt regulációs zavaroktól eltelkintve későbbi kezdetű, mint a 0-3 éves kor, ezért az externalizációs problémákat - tipikusan az oppozíciós zavart, vagyis dacos ellenszegülést és engedetlenséget, vagy az aggreszszióval is párosuló viselkedészavart kezelő szülőtréningek általában idősebb korcsoportokkal dolgoznak. Az externalizációs problémák csökkenését célzó szülőprogramok metaanalízise szerint, az ezekbe a programokba bevont gyermekek tipikusan (kis)iskolás-, esetleg óvodáskorúak, viszont ezeknek a vizsgálatoknak a szintézise is érdekes tanulságokat tartogat.

A hatásvizsgálatok módszertani igényességéhez szükséges, hogy a vizsgálati személyek random módon legyenek vizsgálati és kontrollcsoportba sorolva (illesztett mintákkal), a minta elégséges nagyságú legyen, a vizsgálat használjon kontrollcsoportot, legyen a beavatkozás előtt és után is tesztelés megbízható és valid mérőeszközzel, valamint legyen utánkövetés (Todres \& Bunston, 1993). A szülőtréningek eredményességét befolyásoló tényezők között a szülők alacsony iskolai végzettsége és foglalkoztatottsága, a kezelés előtt a gyermekek viselkedési problémáinak súlyosabb foka, és az anyai pszichopatológia jelenléte mérsékelt hatásfokú tényezőknek tűntek, egyedül az alacsony családi jövedelem tünt nagy hatásfokúnak (Reyno \& McGrath, 2006). Sajnálatos módon általában azok a legveszélyeztetettebbek a lemorzsolódás szempontjából, akik leginkább profitálhatnának a szülősegítő tréningekből, ők a gazdaságilag hátrányos helyzetűek vagy társadalmilag izoláltak. 
Vannak kísérletek arra, hogy az idősebb korosztályoknál eredményes szülőtréningeket kiterjesszék a fiatalabb korcsoportokra is, ezáltal a jelentkező problémákat csírájukban kezelhessék. Ezeknél a programoknál azonban nagyon fontos, hogy a tipegö korosztályra legyen adaptálva a program. A nemzetközi gyakorlatban két olyan program van, mely a korai életévekben is hatékonynak tünik, és költséghatékonyan megvalósítható (Moran et al., 2004, Danis, 2020b). Ezek egyike a Webster-Stratton-féle egyesült államokbeli Incredible Years program $^{4}$, a másik az ausztrál Triple-P program ${ }^{5}$ (Sanders, 2008). Mindkét program többszintű, különböző célcsoportokra kidolgozott protokollokkal.

A szülősegítő programok tekintetében fontos kérdés, hogy milyen jellegü és mekkora mértékủ pozitív változásokat remélünk tőlük. Ezen kívül minden program esetében kérdés, hogy mekkora a hatásköre, milyen társadalmi réteget és mekkora számban ér el. Az érdeklődőket milyen módon motiválja a részvételre? Az ingyenesség jó incentíva lehet, de sokszor nem elégséges feltétel a résztvevők számának maximalizálására. Lényeges kérdés, hogy a program célcsoportjába tartozók nyitottak-e a részvételre. Még a bizonyítottan hatásos programoknál is felmerül, hogy a való életben meghirdetett szülőtréningek nem tudják ugyanazokat az eredményeket felmutatni, mint amelyeket a hatásvizsgálatok magukénak tudhattak. Sok múlik azon, hogy sikerül-e a segítségre szoruló szülőket elérni, a programba bevonni, hogyan történik a kommunikáció és a kapcsolattartás az érdekeltekkel, mennyi energiát sikerül fektetni a résztvevők programban tartására (Axford et al., 2012).

A hatásvizsgálatok általában a gyermekeknél a problémás viselkedés csökkenését nézik, illetve azt, hogy milyen tényezők járultak hozzá a gyermeknél tapasztalható pozitív változáshoz. Mindazonáltal az ilyen programoknak prevenciós céljai is lehetnek. Egyrészt a szülők érzékenyíthetők arra, hogy nevelésükkel hatást gyakorolnak a gyermekük önértékelésére, másrészt arra is felkészíthetők, hogyan küzdjenek meg a rájuk váró stresszes gyermeknevelési periódusokkal (Todres \& Bunston, 1993). A továbbiakban megvizsgáljuk a szülősegítés prevenciós formáit.

\section{A szülösegítés prevenciós formái}

A prevenciót többféle értelemben használhatjuk. A szülői létre való felkészítés, az egészséges gyermeki fejlődésről való információk átadása is prevenciós jellegű a szülői létre készülő párok számára: várandós csoportok, szülői hivatásra felkészítés keretében (Danis, 2020a).

A gyermeket nevelőknél előfordulhat, hogy ismeretek vagy készségek hiánya, esetleg téves attitűdök okoznak kapcsolati problémát a szülö-gyermek diádban. Prevenciós jellegű a szülőedukáció is, mely olyan „egyértelmü tartalommal, célcsoporttal és célokkal kialakított beavatkozás, mely a szülői kompetencia erősítését és/vagy a szülői viselkedés megváltoztatását célozza,

\footnotetext{
${ }^{4}$ https://www.incredibleyears.com

${ }^{5}$ https://www.triplep.net
} 
a gyermekek pozitív fejlődési kimenetének támogatása érdekében." (Cs. Ferenczi, 2019, p. 5). A szülőedukáció a szülői képességekre, érzésekre, vélekedésekre és feladatokra irányul. A szülők olyan tapasztalatokat szereznek általa, melyek hozzájárulnak ismereteik bővüléséhez és feladatkörük, valamint saját és gyermekeik reakcióinak jobb megértéséhez (Cs. Ferenczi, 2019).

Tipikus fejlődésmenet, illetve a patológia hiánya esetén is előfordulhat, hogy a szülők elveszettnek érzik magukat a gyermeknevelés kihívásai közepette. Az is elképzelhető, hogy a gyermeknél látunk már problémás viselkedést, de nem olyan súlyos, hogy klinikai diagnózist kaphatna. A súlyosabb viselkedésprobléma kialakulásának megelőzését, illetve a szülö-gyermek kapcsolat javítását is célozhatják a preventív jellegű szülősegítő formák.

Léteznek csoportos, tematikával rendelkező, készségfejlődést, illetve attitűdváltozást elérni szándékozó, szakemberek vezette szülőtréningek. Ezek közül alábbiakban bemutatunk néhányat, melyekről Magyarországon megjelent könyv, illetve amelyek elérhetők tréning formájában is. A három éven aluli gyermekek szüleinek (is) szóló szülőtréningek közt találunk hatásvizsgálattal rendelkezőket és olyanokat is, melyek hatékonyságát még nem sikerült vizsgálatokkal igazolni.

A humanisztikus pszichoterápiában gyökerezik a Gordon-módszer (Gordon, 1995), melynek szülőket célzó változata a P.E.T., vagyis szülői eredményesség tanítása ${ }^{6}$ (parental effectiveness training). A Gordon-módszernek több hatásvizsgálata volt, ezekről metaanalízis is készült (Cedar \& Levant, 1990). A hatásvizsgálatok képesek voltak egyértelmű, de kis változást tetten érni a szülők tudása, attitüdje, magatartása és a gyermekek önértékelése tekintetében, és ezek a hatások a programok befejezése után - akár 26 hétig - is fennmaradtak (Cedar \& Levant, 1990). A Gordon-módszert a magyar bölcsődékben a kisgyermeknevelők továbbképzésére használják, a gyakorlati tapasztalatok alapján a módszer elemei - a probléma tulajdonosának azonosítása, értő figyelem, közléssorompók kerülése - a legkisebb korosztállyal is működőképesek (a Gordon-módszer magyar kisgyermeknevelésben való alkalmazásának tapasztalatairól lásd Pusztainé Berényi, 2015).

A gyermekekkel való beszélgetésért és a gyermekek megértéséért küzdő Haim Ginott elképzeléseire épülő szülőtréningeknek ${ }^{7}$ szintén van hatásvizsgálata (Mireille et al., 2014), noha kontrollcsoport nélküli. Haim Ginott módszerének leírásai Magyarországon könyv formában elérhető saját könyvében (Ginott, 2015), illetve tanítványainak tolmácsolásában Beszélj úgy, hogy érdekelje, hallgasd úgy, hogy elmesélje (Faber \& Mazlish, 2013), illetve Testvérek féltékenység nélkül (Faber \& Mazlish, 2014) címmel.

Az EMK, vagyis Erőszakmentes vagy Együttműködő kommunikáció módszere ${ }^{8}$ Marshall Rosenberg elképzeléseire épül (Rosenberg, 2001). An-

\footnotetext{
${ }^{6}$ https://www.gordontrening.hu/gordonszuloknek

${ }^{7}$ https://fabermazlish.com

${ }^{8}$ https://emk.hu
} 
nak ellenére, hogy az EMK-t már majdnem fél évszázada oktatják szülőknek (Rosenberg, 2005), ezeknek a szülőcsoportoknak még nem született tudományos folyóiratban publikált hatásvizsgálata. Az EMK empátiára gyakorolt hatását vizsgálták ápoló hallgatóknál (Nosek et al., 2014) és széles körben használták rabok (Suarez et al., 2014), valamint házaspárok (Islam \& Naher, 2017; Vazhappilly \& Reyes, 2017) kommunikációs készségeinek fejlesztésére.

Az adleri gyökerü pozitív fegyelmezés ${ }^{9}$ (Nelsen, 2013)) a fentebb említett szülőtréningekhez hasonlóan békés eszközökkel kíván tisztelettudó gyermekeket nevelni. Angol nyelven tréning, könyv, online felület, audio- és videófelvételek valamint applikáció is elérhető a kurzus tartalmaihoz (Gfroerer et al, 2013), magyarul könyv és tréning segíti a szülőknek a pozitív fegyelmezés készségeinek elsajátítását. Hatásvizsgálatot nem találtunk a módszerhez, azonban egy önbevallásos szülői pozitív fegyelmezési skála már készült a tréninghez (Carroll \& Hamilton, 2016).

Az egyszerűsítés filozófiáját valló Kim John Payne szülőtréningje az Egyszerü nevelés (Simplicity parenting) névre hallgat, a szerző terápiás tapasztalatain alapuló módszer. Hatásvizsgálattal nem rendelkezik, magyarul könyvek Egyszerübb gyermekkor - Hogyan neveljünk nyugodtabb, boldogabb, magabiztosabb gyerekeket? (Payne, 2013), Melegszivü fegyelmezés (Payne,

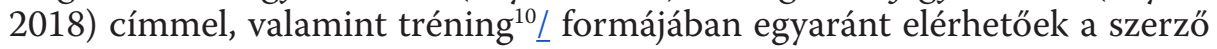
tanácsai.

A Kapcsolódó nevelés program ${ }^{11}$ a Wipfler-féle Hand in Hand Parenting magyarra fordított változata. Az Amerikai Egyesült Államokból származik, mára Magyarországon is elérhető. A program öt módszer - gyerekidő, sírás és hiszti meghallgatása, határszabás, nevetés meghallgatása, páros meghallgatás - segítségével törekszik a szülö-gyermek kapcsolat erősítésére és az erőszakmentes gyermeknevelésre (Shore \& Wipfler, 2021). Olyan tanulmány is született, amely az egyes módszerek kutatási megalapozottságát kereste a szakirodalomban (Aced-Molina, 2012). A szervezet angol nyelvü honlapja szerint a hatásvizsgálatok megkezdődtek (Oatis et al., 2014).

A fenti egyesült államokbeli programokon túl létezik több évtizedes múltra visszatekintő magyar szülősegítés is a Pikler Ház kínálatában. A Pikler-örökséget gondozó Pikler Ház munkatársai többféle szülőtámogatást nyújtanak: egyrészt többféle szülőedukációt, másrészt egy különleges formában zajló JátékTér nevü szolgáltatást.

A Pikler-pedagógia szülők számára való közvetítése mindig is fontos volt Pikler Emmi és munkatársai számára, ezért könyveket is írtak a szülők számára. Ezek közül az ismertebbek a Mit tud már a baba? (Pikler, 1940), illetve az Anyák könyve (László \& Péterné Pikler, 1967). A Pikler Ház munkatársai (Tardos Anna, dr. Majoros Mária, dr. Borbély Sjoukje, Mózes Eszter és Tényi

\footnotetext{
${ }^{9}$ http://pozitiv-fegyelmezes.hu/szuloknek

${ }^{10}$ https://egyszerubbgyerekkor.hu

${ }^{11}$ https://kapcsolodoneveles.hu
} 
Vera) készítettek egy tizenkét részes gyermekfilmet, illetve egy képeskönyvet A baba elsö lexikonja I-II. címmel (Tardos et al., 1983).

A Pikler Ház szülőedukációs előadásai meghatározott témák köré szerveződnek. A négyalkalmas Gyermekváró ${ }^{12}$ program során a várandós szülők csoportos felkészítése történik a gyermek születésére, ezen belül is a gondozásra, az újszülött sajátosságaira, viselkedésére, megfigyelésének jelentőségére. A Testvér születik ${ }^{13}$ csoport ugyancsak négyalkalmas, itt a kistestvér születésére való felkészülés a téma Pikler Emmi elgondolásai alapján. A Mühelybeszélgetése ${ }^{14}$ egy előadássorozat, alkalmankénti csatlakozási lehetőséggel.

A kisgyermekes szülőknek kínálnak egy Magda Gerber által megálmodott, német nyelvterületen elterjedt JátékTér ${ }^{15}$ nevü szolgáltatást is, melynek során a szülők 6-24 hónapos kisgyermekükkel egy játszószobában töltenek el egy órát. A szülőnek az a feladata, hogy megfigyelje, gyermeke hogyan játszik önállóan, más gyermekek társaságában. A JátékTér vezetőinek egyike a gyermekek biztonságára felügyel és kíséri játékukat, másikuk pedig a szülők felfedezéseit, megfigyeléseit támogatja. A JátékTér foglalkozások kiegészülnek szülői konzultációkkal. Ezeknek a foglalkozásoknak célja a szülők attitűdformálása és a megfigyelési készségeik fejlesztése. A Pikler szülőtámogató szolgáltatások népszerűek a kisgyermekes szülők körében, de sajnos nincs hatásvizsgálatuk.

\section{A távsegítés formái}

A távsegítés már az internet előtt is létezett, az írott szó, illetve hang-vagy filmfelvételek rádiós, televíziós közvetítése révén. Ezek a formák azonban csak az egyirányú kommunikációt tették lehetővé, a nevelési tudás birtokosától a szülők felé. Ez alól kivételt jelentett azon szülők szűk köre, akik kérdéseiket levélben fogalmazták meg a szakembereknek, magazinok nevelési rovataiba, és akiknek levele nyilvános választ kapott (például Falk \& Tardos, 1985).

Napjainkban az online tartalmak között a legkönnyebben megtalálhatók és fogyaszthatók a nevelési kérdésekre választ kínáló rövid írásos anyagok. Ezek problematikája ugyanakkor épp a rövidségük, mivel komplex problémákra nehéz egyszerủ válaszokat adni - kimondottan úgy, hogy nem feltétlenül illik ugyanaz a megoldás a különböző családok nehézségeire. Az ingyenesen hozzáférhető írások az interneten nagyon különböző szerzőktől származnak. A szerzők között vannak szülői tapasztalattal rendelkező laikusok, kompetensebb, az átlagnál tájékozottabb tartalomgyártók, valamint

\footnotetext{
${ }^{12}$ https://www.pikler.hu/gyermekvaro

${ }^{13}$ https://www.pikler.hu/testver-szuletik

${ }^{14}$ https://www.pikler.hu/muhelybeszelgetesek

${ }^{15}$ https://www.pikler.hu/jatekter
} 
szakértők egyaránt. A nevelési irányzatok és elvek tekintetében a szerzők különböznek abban, hogy saját pedagógiai álláspontjuk mellett érvelnek, vagy hajlandóak-e több különböző megközelítés, módszer előnyeit és hátrányait is ismertetni. Az internetes cikkeken túl a blogok - vagy akár a vlogok túlnyomóan egyirányú kommunikációs formák. Noha lehetőség van kommentelés révén visszajelezni, hozzászólni a tartalomhoz, azonban a témát alapvetően a blog írója, illetve a vlogoló határozza meg, mivel a blogírás és a videókészítés sokszor saját szülői élményeinek feldolgozását segíti.

Az interaktívabb közösségi média felületein - a Facebook-on, illetve bármilyen hasonló rendszerben működő fórumon -, rengeteg nevelési kérdéssel foglalkozó szülői csoportot találunk. Ezek között vannak szakértők által moderált oldalak, valamint olyanok is, ahol a szülők adnak tanácsot egymásnak. A veszélyt az jelentheti, hogy a szülők gyakran figyelmen kívül hagyják, hogy egy-egy nevelési megoldás nem csak azért müködik számukra, mert jól választottak a nevelési eszköztárból, hanem azért is, mert gyermekük temperamentuma vagy egyéb adottságai hasonlóak az övékhez, azaz jól illeszkednek egymáshoz, illetve környezeti, társas tényezők is támogatják őket a nevelésben. Így a jól müködő szülőnek az a meggyőződése, hogy ami neki működött, az másnak is fog, a nevelés soktényezős hatásai közül többet figyelmen kívül hagy, vagy saját szülői szerepét túlértékeli a folyamatban. Az online közösségek önsegítő funkciója ugyanakkor mindenképp elismerésre méltó jellemző. A kisgyermekkel otthon levő szülőknek a kapcsolódás érzését ad(hat)ják, a tagok támogat(hat)ják egymást az eddig nem tapasztalt életállapot kihívásai közepette.

\section{Kapcsolat nélküli offline távsegítési forma: nevelési könyvek}

A szülőknek írt gyereknevelési irodalmaknak tekintsük át egy szeletét, például a gyermekek irányítását. Harmincöt, 90\%-ban 2000 után megjelent, Magyarországról elérhető, a három éven aluli kisgyermeknevelést is érintő gyermeknevelési könyvet tekintettünk át ebben a témában, amelyek könyvkötészeti adatait a tanulmány végén, egy külön jegyzékben szerepeltetjük.

A laikus irodalomban a módszerek leírásai konkrétak. Ismertetnek problémás eseteket, jól körülírt megoldási javaslatokkal. Vannak olyan szerzők, akik a kontraproduktív viselkedésmódokat is ismertetik. A konkrétság egyben hátrányt is jelent, mivel fennáll a veszély, hogy a nevelési tanács merevvé válik, varianciákat nem ismer el (például Hogg \& Blau, 2003; Lansbury, 2015), „receptkönyvvé” silányul.

Számos laikus kisgyermeknevelési mü felfogható vitairatnak is. Hardyment (2007) történeti müvében a gyermeknevelési tanácsokat John Locketól Gina Ford-ig tekinti át. Bemutatja, hogy a laikus irodalomban a nevelési tanács generációnként változik az aktuálisan követendőnek tartott gyermeknevelési divatok mentén. Ez azt jelenti, hogy az érvelés ellenpontja is megváltozik. A laikus irodalmakban gyakori, hogy a szerző egy állásponttal vagy 
nevelési gyakorlattal szemben építi fel érvelését. Találunk olyan műveket, melyek a ráhagyó, megengedő, kényeztető neveléssel szemben foglalnak állást (például Grosshans \& Burton, 2009; Winterhoff, 2012; Rogge, 2013; Cloud \& Townsend, 2016), és olyanokat is, melyek a tekintélyelvű neveléssel szemben (Faber \& Mazlish, 2013; Nelsen, 2013; Ginott, 2015)

A szerző kilététől és nézőpontjától függően e könyvek eltérnek stílusukban, hangsúlyaikban egymástól, mint ahogy abban is, hogy az író milyen nevelési problémákra ad választ. A nevelési problémák körét merítheti a szerző saját szülői tapasztalataiból (például Chua, 2011; Druckerman, 2012; Süveges, 2012), vagy kisgyermeknevelő/dada (nanny) tevékenységéből (például Hogg \& Blau, 2003.; Frost, 2011; Lansbury, 2015), illetve szülőkkel vagy gyermekekkel végzett terápiás munkájából (például Byron \& Baveystock, 2006; Latta, 2014; Payne, 2013; Ginott, 2015).

A saját, jól bevált gyakorlatukon túl a laikusoknak szóló gyermeknevelési könyvek szerzői hivatkozhatnak empirikus kutatások eredményeire. Ezt többféleképp teszik. Egyrészt mások kutatási eredményeit értelmezik a nagyközönség számára (például Gerhardt, 2009; Aamodt \& Wang, 2012; Bronson \& Merryman, 2014), illetve mások kutatási eredményeit használják fel az általuk választott nevelési módszerek alátámasztására (például Vida, 2011; Siegel et al., 2015).

Ritkán előfordul az is, hogy egy szerző klinikai mintán empirikusan kidolgozott intervenciós módszerét ismerteti a szélesebb közönséggel (Kazdin, 2009). Összességében tehát keresik az empirikus eredményekkel való kapcsolatot, de inkább az empíria és a gyakorlat határmezsgyéjén helyezkednek el. A laikus szülők számára a tájékozódás a széles kínálatban nem feltétlenül egyértelmű vagy egyszerü.

\section{Videós tartalmak a szülök támogatására}

Multimédiás tartalom lehet az írásos cikkek analógiájára az online előadás, illetve a blogok videós megfelelője a vlog, amelyről korábban szóltunk már. Számos pszichológus, pedagógus szakértő előadása elérhető ingyenesen a YouTube videómegosztón, akár egy-egy önálló előadás, akár egy-egy szervezet által tematikusan rendezett előadássorozat.

Számos olyan ismeretterjesztő vagy dokumentumfilm érhető el napjainkban, amely a csecsemők és kisgyermekek sajátosságait, élményvilágát, fejlődését mutatja be (például Thomas Balmes Babák - az első év című 2010-es dokumentumfilmje, vagy a Netflix 2020-as Babies címü 12 részes dokumentumfilm-sorozata).

A kisgyermekes szülők világáról is készült már valóságshow, ezek közül a segítő szándékúakról szólunk. Jo Frost nevelőnői tapasztalatai alapján a Szuperdada visszatér (Extreme Parental Guidance) címü sorozatban segíti a szülőket, hogy engedetlen gyermekeikkel szót értsenek. A klinikai szakpszichológus Tanya Byron egy videókamerákkal felszerelt házba költözteti be az 
intervenciót kérő családokat a Vásott kölykök (The House of Tiny Tearaways) címü BBC Three tévésorozatában. A valóságshow-k egyszerre próbálnak az ismeretterjesztés és a szórakoztatás céljának megfelelni. Különlegességük, hogy betekintést engednek az intervenciós folyamatba, azonban a szórakoztatóipar feszültségre és drámai pillanatokra való éhsége, és ezeknek a müsorokban való hangsúlyozása torzíthatja a laikusok intervencióról alkotott elképzeléseit.

\section{Preventív online szülösegítö applikációk, kurzusok}

Léteznek szakértők által tervezett, de a szakértőkkel való interakció lehetőségét nem kínáló angol nyelvű telefonos applikációk (például a Kinedu vagy a BabySparks), melyekkel a szülő gyermekének fejlődését követheti és támogathatja. A Kinedu 0-2 év közötti gyermekek napi szintű fejlesztését elősegítő, fizetős telefonos applikáció. A regisztráció során ki kell tölteni a gyermekről, hogy mikor született és hányadik hétre, az applikáció számításba tudja venni a koraszülöttséget is. A fejlődési mérföldköveket lehet regisztrálni, az újonnan megszerzett készségeket rögzíteni. A különböző fejlődési területeken elért előrelépések nyomon követhetők a grafikus megjelenítés segítségével. A gyermek aktuális fejlettségnek megfelelően egy óriási videós gyakorlatgyűjteményből naponta négy gyakorlatot ajánl az applikáció. A gyakorlat kivitelezését és hasznát 1-1,5 perces videóban mutatják be. Késznek lehet jelölni a javasolt gyakorlatokat, ezekhez néha kérdést is kap a szülő, hogy a gyermekén a gyakorlat közben mit látott. Ezek a kontroll kérdések még inkább segítenek a gyermek fejlettségi profilját leírni. Személyre szabhatóak a napi gyakorlatok, ha túl könnyünek vagy nehéznek találunk egyegy gyakorlatot. Lehet új gyakorlatot kérni, ha olyan eszközhasználatra épül, amely nem áll rendelkezésre. Az egyes elérendő képességekhez tipikus fejlődésmenet statisztikák, időintervallumok is társulnak, hogy a szülő észrevegye a fejlődésbeli elmaradást. A napi gyakorlatokhoz szülősegítő cikkek is társulnak, amelyek egy-egy egészségügyi vagy nevelési kérdésben nyújtanak további kapaszkodót. Az applikáció a tartalommal interaktív, de nem kínál személyes kontaktust szakemberekhez, tanácsadókhoz. Pozitívuma, hogy hangsúlyt fektet a gyermekkel közös időre, a fejlődés megfigyelésére és regisztrálására.

A szülősegítés egy másik formája az interaktivitást is tartalmazó tanácsadás vagy specifikus szülői készségfejlesztés, mely leggyakrabban ingyenes és fizetős tartalmakat felvonultató üzleti modellben valósul meg. (1. táblázat) Az ingyenes tartalmak a marketing részét képezik. A tartalmat a felhasználó is generálja fórumban, facebook csoportban. Többszintủ tagsági rendszerben az előfizetés mértékétől függ a tartalmakhoz való hozzáférés. A szolgáltatók igyekeznek magas minőségű tartalom előállítására, miközben folyamatosan erőfeszítéseket tesznek az új vevők beszervezésére. A pozitív felhasználói visszajelzések a marketing részeként is megjelennek. A szakér- 
tő konzultációs ideje a legdrágább termék ezekben a szolgáltatásokban, az egyéni problémára való adaptálás többnyire a szülő feladata. Nincs információ arról, hogy a szülők milyen problémákkal keresik fel ezeket a szolgáltatásokat, milyen módon vesznek részt bennük és milyen arányban oldódnak meg a gyermekeknél a problémák.

\section{1. táblázat}

Példák magyarországi üzleti modellben müködő szülői készségfejlesztési programokra

\begin{tabular}{|c|c|c|c|}
\hline honlap - oktató & témakör és cím & elemek & interaktivitás \\
\hline $\begin{array}{l}\text { anyagyere.hu - } \\
\text { Dénes Ivett }\end{array}$ & $\begin{array}{l}\text { Bababarát } \\
\text { alvástanácsadás }\end{array}$ & $\begin{array}{l}\text { hírlevél, minitré- } \\
\text { ningek, magazin, } \\
\text { könyv, online videós } \\
\text { tananyagok zárt } \\
\text { tagsági oldalon, } \\
\text { online tanácsadás } \\
\text { csoportban, egyéni } \\
\text { konzultáció }\end{array}$ & $\begin{array}{l}\text { facebook csoportok } \\
\text { (többszintű tagsági } \\
\text { rendszer) }\end{array}$ \\
\hline $\begin{array}{l}\text { gyereketeto.hu / } \\
\text { skillo.hu - Sárosdi } \\
\text { Virág }\end{array}$ & $\begin{array}{l}\text { Fejlesztő játékok, } \\
\text { tanfolyamok szü- } \\
\text { lőknek a gyermekük } \\
\text { készségfejlesztéséhez }\end{array}$ & $\begin{array}{l}\text { hírlevél, tanfo- } \\
\text { lyamok (gyermek } \\
\text { fejlesztésére, illetve } \\
\text { szülői készségfej- } \\
\text { lesztésre), fejlesztő- } \\
\text { eszközök, LapBook, } \\
\text { zárt tagsági oldal a } \\
\text { tananyagokkal }\end{array}$ & $\begin{array}{l}\text { tanfolyam- előfize- } \\
\text { tőknek }\end{array}$ \\
\hline $\begin{array}{l}\text { babakezek.hu - } \\
\text { Zentai Kata }\end{array}$ & $\begin{array}{l}\text { Babajelbeszéd és a } \\
\text { Beszélő Babakezek } \\
\text { módszer }\end{array}$ & $\begin{array}{l}\text { hírlevél, webináriu- } \\
\text { mok, tanfolyamok }\end{array}$ & $\begin{array}{l}\text { tanfolyami zárt } \\
\text { csoport }\end{array}$ \\
\hline $\begin{array}{l}\text { domokoskata.hu - } \\
\text { Domokos Kata }\end{array}$ & $\begin{array}{l}\text { Anyatöltő - } \\
\text { édesanyák meg- } \\
\text { oldásközpontú } \\
\text { támogatása, life- és } \\
\text { business coaching }\end{array}$ & $\begin{array}{l}\text { hírlevél, könyvek, } \\
\text { kurzusok, egyéni } \\
\text { coaching }\end{array}$ & $\begin{array}{l}\text { facebook csoportok } \\
\text { (ingyenes és fizetős) }\end{array}$ \\
\hline
\end{tabular}

\section{Online evidence-based szülötréningek - külföld}

Az interneten keresztül a felhasználók elérését nemcsak az üzleti szférában, hanem a pszichopatológia tekintetében veszélyeztetett populációk esetében is felismerték a szolgáltatók. A nehezen elérhető populációk megszólítására, majd a Covid19-járvány miatti lezárások kényszerủségéből megszaporodtak a webalapú tréningek. Az eredetileg szülőcsoportokkal dolgozó bizonyítottan hatékony programoknak mára vannak hibrid vagy teljes mértékben online, saját ütemben végezhető verziói is. A hibrid verzióban a szülő „önadagolásos" (self-administered) módon végzi a tréninget, azonban a motivációját fenntartandó telefonhívásokat kap a tréning szolgáltatójától (például 
Taylor et al., 2008; Day \& Sanders 2018). Ezeknél a programoknál a távolléti szolgáltatásra való áttérés abból a szempontból elő volt már készítve, hogy például az Increadible Years program már a személyes találkozókon alapuló csoportokban is videórészletekkel és hanganyagokkal illusztrálta a szülök számára az elsajátítandó viselkedésformákat (Taylor et al., 2008), azaz már ekkor is erősen támaszkodtak médiatartalmakra.

A Triple-P program esetében a már bizonyítottan hatékony jelenléti formát hasonlították össze az online megvalósított tréninggel. Az óvodáskorú gyermekek szüleinek nyújtott távolléti tréning legalább olyan olyan hatékonynak bizonyult, mint a jelenléti tréning (Prinz et al., 2021). Pozitívum ezeknél a programoknál, hogy a különböző tréningvariációkról is van elérhető hatásvizsgálat, például a Triple-P program esetében a szülőknek szóló podcastok hatékonyságát is vizsgálták. Az eredmények arra utalnak, hogy érdemes a személyes találkozásokon túl, más formákat is használni a tartalom kialakításánál, mivel ezek révén is lehet változást hozni a gyermekek életébe (Morawska et al., 2014).

Több metaanalízis is áttekintett digitális szülőtréningeket napjainkig (Christa et al., 2013; Breitenstein et al., 2014; Corralejo \& Rodríguez, 2018; Hansen et al., 2019). Már a 2010-es évek elején is úgy tűnt, hogy a digitálisformában kínált szülőtréningek is képesek a társas támogatásra, a szakemberekkel való konzultációra és szülői kompetenciák fejlesztésére (Christa et al., 2013). A hosszabb (több üléses, több hetes) tréningek teljesítési arányai általában alacsonyabbak a rövidebbeknél (Breitenstein et al., 2014). Két metaanalízis is arra hívta fel a figyelmet, hogy kérdéses, hogy a veszélyeztetett populációk számára a digitális tréningek mennyire elérhetőek és teljesíthetőek (Corralejo \& Rodríguez, 2018; Hansen et al., 2019).

Ritka, hogy a publikációk negatív eredményt ismertetnek, de ilyet is találtunk. Az ezParent program a bizonyítékokon alapuló Chicago Parent Program digitális adaptációja a kezdeti bíztató eredményeket felmutató pilot vizsgálat után a nagyobb mintán 2015-ben elvégzett randomizált hatásvizsgálatban nem bizonyult eredményesebbnek, mint a kontrollcsoport (Breitenstein et al., 2021). 2-5 éves gyermekek szüleit egészséges tanácsadáson informálták a vizsgálatban való részvétel lehetőségéről. A súlyosabb problémákat mutató gyermekek családjaiban a szülői készségek javulásához hozzájárult ugyan a program, de csoportszinten nem volt szignifikáns különbség az intervenciós ezParent és a hagyományos védőnői információkat kapó kontrollcsoport közt. A szerzők szerint a teljesen önálló ütemezésü (ön-adagolós) forma is lehetett az oka annak, hogy a program nem volt hatékony, megoldásként a szerzők a szakértő elérhetősége melletti hibrid formát javasolták (Breitenstein et al., 2021).

Ausztrál szülőknek ingyenes, csak online elérhető program a $\mathrm{Pa}$ rentWorks ${ }^{16}$. A program a gyermek viselkedési problémákra fejlesztett, integrált családi intervenció [Integrated Family Intervention for Child Conduct

${ }^{16} \mathrm{https} / / /$ parentworks.org.au; a világ más területeiről nem elérhető 
Problems (Dadds \& Hawes, 2006)] online, szélesebb populációra adaptált változata 2-16 éves gyermeket nevelő szülőknek. A regisztrációkor, a kurzus befejezésekor és 3 hónappal a befejezést követően a résztvevők kérdőívet töltenek ki, melynek segítségével a tervezők a program hatékonyságát mérni tudják. A program összesen 6 modult tartalmaz, melyből öt törzsmodulnak számít, a modulok egyéni ütemezésben teljesíthetőek. Regisztrációkor az első két modul elérhető, majd hetenként jelenik meg az új modul, hogy a szülők ki tudják próbálni a javasolt stratégiákat. Egy modul 20-30 perces időráfordítást igényel. 2018-ra közel háromezer szülő vett részt a programban (Dadds et al., 2019). A program fontos jellemzője, hogy az apák részvételére buzdít: a résztvevők 40\%-a férfi volt! A résztvevőket a teljesítés függvényében csoportokba sorolták: $55 \%$ regisztrált, de nem fejezett be egyetlen modult sem (tájékozódók). 39\% teljesített legalább egy modult, de vagy félbehagyta a kurzust, vagy nem töltötte ki a kurzuszáró kérdőívet (félbehagyók). A kezdeti nagy lemorzsolódás után hétről-hétre csökkent a modulokat teljesítők száma. A 2967 résztvevőből mindösssze 218 teljesítette a kurzust (teljesítők).

Megvizsgálták, hogy milyen tényezők hatottak a kurzus teljesítésére. A félbehagyóknak kisebb gyermeke volt, súlyosabb viselkedési problémával, amelyre több diszfunkcionális szülői viselkedéssel válaszoltak. Tehát a szülő számára abban az esetben volt motiválóbb a kurzus teljesítése, amikor gyermeke kisebb viselkedési problémával rendelkezett és már idősebb volt, ekkor kitartóbbnak bizonyult abban, hogy gyermeke problémás viselkedésével megküzdjön.

A félbehagyók között több volt az egyetemi diplomás, mint a tájékozódók közt. Érdekes módon a teljesítők körében az egyedülálló szülők magasabb arányban voltak, mint a másik két csoportban. Az eredmény rámutat arra, hogy az online kurzus alkalmasabb lehet az egyedülállók számára, mint a jelenléti tréningek, hiszen a szülőnek nem kell gyerekvigyázót találnia a tréning idejére, mivel akkor végezheti a kurzust, amikor számára megfelelő. A körülnézők között volt a legmagasabb a szülők körében észlelt pszichológiai nehézségek aránya. Gyakori probléma, hogy a pszichés nehézségek megakadályozzák a szülöt, hogy részt vegyen abban a programban, ami segítene nehézségeinek csökkentésében (Dadds et al., 2019). Ez azért szomorú, mert a gyermekek profitálnának abból, ha a nehézségekkel küzdő szüleik elvégeznék a tréninget.

Azoknál a gyermekeknél, akik szülei súlyosabb viselkedési problémákat jeleztek a program kezdetekor, nagyobb javulást találtak, mint azoknál, akiknél kevesebb problémát jeleztek a tréning kezdetén a szülők (Piotrowska et al., 2020).

\section{Angol nyelvü MOOC szülöknek}

A MOOC tömeges nyílt online kurzus, a szülősegítés esetében egy lehetséges keret a tartalom közvetítéséhez. Ez az oktatási forma képes az egyetemek kapuit az érdeklődők tömegei előtt kinyitni egy-egy rövidebb kurzus erejéig. A hagyományos egyetemi oktatáshoz képest ez jelentős változást hoz az ismeretek továbbadásában. 
A Coursera oldalán Alan Kazdin a Yale Egyetem oktatója tart online kurzust, melynek címe Everyday Parenting: The ABCs of Child Rearing. A kurzusra ezidáig 136 000-nél többen iratkoztak be. A kurzus gyakorlatorientált, a szerző klinikai és kutatási eredményein alapszik (melyeket már könyvében is tárgyalt: Kazdin, 2009). A gyermek nemkívánatos viselkedésének megváltoztatásához szükséges szülői technikákat, valamint az ezekkel kapcsolatos tévhiteket mutatja be, az előzmények, a viselkedés és a következmények kontextusában. Az oktatóvideókhoz kvízek is tartoznak. A kurzus jól érthető, és jól hasznosítható: a szülő által azonosítandó, részleteiben átgondolandó konkrét problémára nyújt lépésről-lépésre kipróbálható és kipróbálandó gyakorlati megoldásokat a viselkedésformálás módszereivel.

Az EdX felületén a San Diego-i University of California oktatója, David Barner tartja a The Science of Parenting címü kurzust, melynek napjainkig mintegy 40000 hallgatója volt. A kurzus olyan témákat vesz végig, melyek a szülők számára érdekesek lehetnek, ezek egymáshoz közel álló témák mentén csoportosulnak modulokba (1. Természet és öröklés, örökbefogadás és viselkedésgenetika; 2 . Nyelvelsajátítás; képernyő; napközbeni gyermekellátás és óvoda; zene; 3. Erkölcs; önkontroll; családi struktúra; 4. Autizmus és oltás; alvás; diéta és szoptatás; 5 . Tanulás és iskola: lemaradók; tanulási stílusok; akkceleráció; otthonoktatás). Nem definiálja, hogy csak szülők vehetnek-e részt a kurzuson, ugyanakkor alkalmanként olyan feladatot ad, amelyet saját gyermek vonatkozásában lehet végiggondolni. A kurzusban említett példák többségében óvodás-kisiskolás korosztály szerepel. Az átadni kívánt tartalom komplex, így a témában való előzetes jártasság megkönnyíti a megértést. A kurzust szakértői interjúk színesítik. A modulzáró kvízek és a projektek csak akkor végezhetők el, ha a személy befizeti a kurzus díját, betekintés mellett nem. A modulzáró projektekben fejlődéslélektani vizsgálatokat ismernek meg a hallgatók, melyeket kitölthető feladatlapok segítségével elemeznek.

A bemutatott két tömeges kurzus példája jól szemlélteti a szülősegítés sokféle arcát: a Kazdin-féle kurzus az intervenciós jellegű szülősegítés jó példája, míg a Barner-féle $A$ szülöség tudománya címü kurzus, inkább ismeretterjesztő, prevenciós vagy tudománydisszeminációs kurzusnak tekinthető.

\section{Összefoglalás}

A szülősegítés számtalan formában, finanszírozásban és tartalommal megvalósulhat. A szülők támogatása sokféle lehet. Néha elegendő az információk nyújtása vagy a támogató meghallgatás. Máskor képzésre, tréningre vagy személyes tanácsadásra lehet szükség. Bármelyik formáról is legyen szó, a cél az, hogy a szülők értsék szülői feladataikat és képesek legyenek ezeknek megfelelni (Daly, 2011).

Irásunkban kísérletet tettünk a szülősegítés módjainak áttekintésére és rendszerezésére. A rendszerezés alapja lehet a hozzáférhetőség, a finanszírozás, a nevelt gyermek életkora, a kurzus jellege (prevenciós vagy interven- 
ciós), a hazai viszonylatban való elérhetőség, a hatékonyságról szóló információk, a jelenléti vagy online forma, illetve a támogató közösség megléte. Napjainkra az online szülősegítő formák megszaporodtak és jó eredményekkel kecsegtetnek, mint a jelenléti kurzusok alternatívái.

\section{Köszönetnyilvánítás}

A szerző köszönettel tartozik Tóth-Mózer Szilviának, Serfőző Mónikának és Gyöngy Miklósnak a kézirathoz nyújtott építő megjegyzéseikért.

\section{Irodalom}

Aced-Molina, R. (2012). A Review of Literature Supporting the Parenting by Connection Approach. http://www.handinhandparenting.org/wp-content/ uploads/2013/08/Full-Lit-Review-2012.pdf (2021.05.03.)

Axford, N., Lehtonen, M., Kaoukji, D., Tobin, K., \& Berry, V. (2012). Engaging parents in parenting programs: Lessons from research and practice. Children and Youth Services Review, 34(10), 2061-2071. https://doi.org/10.1016/j.childyouth.2012.06.011

Biztos Kezdet (2021). A Biztos Kezdet Gyerekházakra vonatkozó minimum követelmények. https://www.palyazat.gov.hu/download.php?objectId=28352 (2021. 04.30.)

Breitenstein, S. M., Fehrenbacher, C., Holod, A. F., \& Schoeny, M. E. (2021). A Randomized Trial of Digitally Delivered, Self-Administered Parent Training in Primary Care: Effects on Parenting and Child Behavior. The Journal of Pediatrics, 231, 207-214. https://doi.org/10.1016/j.jpeds.2020.12.016

Breitenstein, S. M., Gross, D., \& Christophersen, R. (2014). Digital delivery methods of parenting training interventions: a systematic review. Worldviews on Evidence区 Based Nursing, 11(3), 168-176. https://doi.org/10.1111/wvn.12040

Carr, A. (2009). The effectiveness of family therapy and systemic interventions for child-focused problems, Journal of Family Therapy, 31(1), 3-45. https://doi. org/10.1111/j.1467-6427.2008.00451.x

Carroll, P., \& Hamilton, W. K. (2016). Positive Discipline Parenting Scale: Reliability and validity of a measure. The Journal of Individual Psychology, 72(1), 60-74. https://doi.org/10.1353/jip.2016.0002

Cedar, B., \& Levant, R. F. (1990). A meta-analysis of the effects of parent effectiveness training. The American Journal of Family Therapy, 18(4), 373-384. https://doi. org/10.1080/01926189008250986

Corralejo, S. M., \& Rodríguez, M. M. D. (2018). Technology in parenting programs: A systematic review of existing interventions. Journal of Child and Family Studies, 27(9), 2717-2731. https://doi.org/10.1007/s10826-018-1117-1

Cs. Ferenczi, Sz. (2019). Bevezetés. In Cs. Ferenczi Sz. (Ed.), Szülői pszichoedukációs csoportok vezetése. Pszichoedukációs csoportvezetők képzését támogató munkatankönyv (pp. 4-6). Katolikus Szeretetszolgálat. https://www.szeretetszolgalat.hu/sites/ default/files/szuloi_pszichoedukacios_csoportok_vezetese.pdf 
Dadds, M. R., \& Hawes, D. J. (2006). Integrated family intervention for child conduct problems: A behaviour-attachment-systems intervention for parents. Australian Academic Press.

Dadds, M. R.; Sicouri, G.; Piotrowska, P. J.; Collins, D. A.J.; Hawes, D. J.; Moul, C.; Lenroot, R. K.; Frick, P. J.; Anderson, V.; Kimonis, E. R. \& Tully, L. A. (2019). Keeping Parents Involved: Predicting Attrition in a Self-Directed, Online Program for Childhood Conduct Problems. Journal of Clinical Child E Adolescent Psychology, 48(6), 881-893. https://doi.org/10.1080/15374416.2018.1485109

Daly, M. (2011). Building a coordinated strategy for parenting support. Queen's University. https://ec.europa.eu/social/BlobServlet?docId=7986\&langId=en

Danis, I. (2020a). A csecsemő- és kisgyermekkori lelki egészség támogatásának indokoltsága - egy új fókusz a kora gyermekkori intervencióban. In Danis, I., Németh, T., Prónay, B., Góczán -Szabó, I. \& Hédervári-Heller, É. (Eds.), A kora gyermekkori lelki egészség támogatásának elmélete és gyakorlata I. Fejlödéselméletek és empirikus eredmények (pp. 20-44.) Semmelweis Egyetem EKK Mentálhigiéné Intézet. https://semmelweis.hu/mental/files/2020/12/Koragyermekkori-lelki-egeszseg_I-kotet.pdf

Danis, I. (2020b). A kora gyermekkori szülő-gyermek kapcsolatot és lelki egészséget támogató nemzetközi programokról, módszerekről - Fókuszban: a kapcsolatés kötődésalapú intervenciók a kora gyermekkorban. In Danis, I., Németh, T., Prónay, B., Góczán-Szabó, I. \& Hédervári-Heller, É. (Eds.), A kora gyermekkori lelki egészség támogatásának elmélete és gyakorlata II. Módszerek, irányzatok, modellprogramok (pp. 70-104). Semmelweis Egyetem EKK Mentálhigiéné Intézet. https://semmelweis.hu/mental/files/2020/12/Kora-gyermekkori-lelkiegeszseg_II-kotet.pdf

Day, J. J., \& Sanders, M. R. (2018). Do parents benefit from help when completing a self-guided parenting program online? A randomized controlled trial comparing Triple P Online with and without telephone support. Behavior therapy, 49(6), 1020-1038. https://doi.org/10.1016/j.beth.2018.03.002

Deutsch, K., Betlehem, J., Bánfai, B., Jeges, S., Lampek, K., Tancsics, D. D., \& Csima, M. (2019). Parental and health visitor assessment of children development and factors affecting children development assessment in Hungary. Kontakt/ Journal of nursing and social sciences related to health and illness, 21(4), 360-366. https:// kont.zsf.jcu.cz/pdfs/knt/2019/04/05.pdf

Faber, A. \& Mazlish, E. (2013). Beszélj úgy, hogy érdekelje, hallgasd úgy, hogy elmesélje. Gyakorlati tanácsok a sikeres szülő-gyerek kapcsolathoz. Reneszánsz kiadó.

Faber, A. \& Mazlish, E. (2014). Testvérek féltékenység nélkül. Reneszánsz kiadó.

Falk J. \& Tardos A. (1985). Kedves Tipegő! Családi Lap füzete. Lapkiadó Vállalat.

Frigyes, J., \& Molnár, J. E. (2020). Anya-csecsemő terápia a Vadaskert Kórház szakambulanciáján - Szemléleti és módszertani bemutatkozás. In Danis, I., Németh, T., Prónay, B., Góczán-Szabó, I., \& Hédervári-Heller, É. (Eds.), A kora 
gyermekkori lelki egészség támogatásának elmélete és gyakorlata II. Módszerek, irányzatok, modellprogramok (pp. 148-159). Semmelweis Egyetem EKK Mentálhigiéné Intézet. https://semmelweis.hu/mental/files/2020/12/Koragyermekkori-lelki-egeszseg_II-kotet.pdf

Gfroerer, K., Nelsen, J., \& Kern, R. M. (2013). Positive Discipline: Helping Children Develop Belonging and Coping Resources Using Individual Psychology. Journal of Individual Psychology, 69(4), 294-304.

Ginott, H. (2015). Szülők és gyermekek. Edge 2000.

Glenn L. I. (2006). „OER PPP - Power of Positive Parenting, Fall 2006”. Family, Consumer, \& Human Development - OCW. Course 2. https://digitalcommons. usu.edu/ocw_fchd/2

Gordon, T. (1995). P.E.T.; Tanitsd gyermeked önfegyelemre! Studium Effektive.

Gyermekvédelmi törvény (1997). 1997. évi XXXI. törvény a gyermekek védelméröl és a gyámügyi igazgatásról.

Hámori, E. (2020). Csecsemő-szülő kapcsolatdiagnosztika és konzultáció. In Danis, I., Németh, T., Prónay, B., Góczán-Szabó, I., \& Hédervári-Heller, É. (Eds.), A kora gyermekkori lelki egészség támogatásának elmélete és gyakorlata II. Módszerek, irányzatok, modellprogramok (pp. 122-139). Semmelweis Egyetem EKK Mentálhigiéné Intézet. https://semmelweis.hu/mental/files/2020/12/Koragyermekkori-lelki-egeszseg_II-kotet.pdf

Hansen, A., Broomfield, G., \& Yap, M. B. (2019). A systematic review of technology区 assisted parenting programs for mental health problems in youth aged 0-18 years: Applicability to underserved Australian communities. Australian Journal of Psychology, 71(4), 433-462. https://doi.org/10.1111/ajpy.12250

Hardyment, C. (2007). Dream babies. Childcare advice from John Locke to Gina Ford. Frances Lincoln Limited Publishers.

Hoffenkamp, H. N., Tooten, A., Hall, R. A., Braeken, J., Eliëns, M. P., Vingerhoets, A. J., \& van Bakel, H. J. (2015). Effectiveness of hospital-based video interaction guidance on parental interactive behavior, bonding, and stress after preterm birth: A randomized controlled trial. Journal of Consulting and Clinical Psychology, 83(2), 416-429. https://doi.org/10.1037/a0038401

Islam, S., \& Naher, R. (2017). Effectiveness of nonviolent communication (NVC) workshop on marital adjustment. Dhaka University Journal of Biological Sciences, 26(1), 69-75. https://doi.org/10.3329/dujbs.v26i1.46351

Kazdin, A. E. \& Rotella, C. (2009). The Kazdin method for parenting the defiant child. With no pills, no therapy, no contest of wills. Mariner Books.

Kereki, J. (2015, Ed.). Kliensút Kalauz. Educatio Társadalmi Szolgáltató Nonprofit Kft.

Kereki, J. \& Major, Zs. B. (2014, Eds.). Örzők. Egészségügyi alapellátók gyakorlatközpontú kézikönyve. Országos Tisztiföorvosi Hivatal. http://mek. oszk.hu/15800/15817/15817.pdf 
Lannert,J.(2015).Szülősegítésakora-éskisgyermekkorbanMagyarországonésmáshol. Esély, 2015(4), 42-61. http://www.esely.org/kiadvanyok/2015_4/2015-4_1-4_ Lannert_Szulosegites.pdf

László M. \& Péterné Pikler E., (1967). Anyák könyve. Medicina.

Moran, P., Ghate, D., Van Der Merwe, A., \& Policy Research Bureau. (2004). What works in parenting support? A review of the international evidence. DfES Publications. https://dera.ioe.ac.uk/5024/1/RR574.pdf

Morawska, A., Tometzki, H., \& Sanders, M. R. (2014). An evaluation of the efficacy of a triple P-positive parenting program podcast series. Journal of Developmental E Behavioral Pediatrics, 35(2), 128-137. https://doi.org/10.1097/ DBP.0000000000000020

Nelsen, J. (2013): Pozitív fegyelmezés. Reneszánsz kiadó.

Németh, T. \& Hédervári-Heller, É. (2020). Az integrált szülő-csecsemő/kisgyermek konzultáció (ISZCSK) és terápiás kezelés kezdete és fejlődése Magyarországon. In Danis, I., Németh, T., Prónay, B., Góczán-Szabó, I. \& Hédervári-Heller, É. (Eds.) A kora gyermekkori lelki egészség támogatásának elmélete és gyakorlata II. Módszerek, irányzatok, modellprogramok (pp. 106-121). Semmelweis Egyetem EKK Mentálhigiéné Intézet. https://semmelweis.hu/mental/files/2020/12/Koragyermekkori-lelki-egeszseg_II-kotet.pdf

Nieuwboer, Christa C.; Fukkink, Ruben G.; Hermanns \& Jo M.A. (2013). Online programs as tools to improve parenting: A meta-analytic review. Children and Youth Services Review, 35(11), 1823-1829. https://doi.org/10.1016/j. childyouth.2013.08.008

Nosek, M., Gifford, E., \& Kober, B. (2014). Nonviolent Communication training increases empathy in baccalaureate nursing students: A mixed method study. Journal of Nursing Education E Practice, 4(10), 1-15. http://dx.doi.org/10.5430/ jnep.v4n10p1

Oatis, P., Wipfler, P., Klorer, M., McKitrick, T., Canterbury, E., Roe, J., \& Buderer, N. (2014). Listening-based parenting strategies promote stronger parent-child connection. Poszter. Mercy Children's Hospital, Toledo, OH. https://www. handinhandparenting.org/research-downloads/

Paszkoszné Kulcsár, A. (2013). Az óvoda helye és szerepe a mai magyar köznevelési rendszerben.Nevelés-oktatás határon innen és túl - XV. Országos Közoktatási Szakértői Konferencia, 2013. október 8-10. Hajdúszoboszló. https://kiadvany. suliszerviz.com/kiadvanyok/13-kiadvany-2013/325-2013-paszkoszne-kulcsarandrea-az-ovoda-helye-es-szerepe-a-mai-magyar-koznevelesi-rendszerben

Payne, K. J. (2013). Egyszerübb gyermekkor. Hogyan neveljünk nyugodtabb, boldogabb, magabiztosabb gyerekeket? Kulcslyuk Kiadó.

Payne, K. J. (2018). Melegszívü fegyelemezés - kisgyerekkortól kamaszkorig. Kulcslyuk Kiadó.

Pikler, E. (1940). Mit tud már a baba? Medicina Kiadó. 
Piotrowska, P. J., Tully, L. A., Collins, D. A., Sawrikar, V., Hawes, D., Kimonis, E. R., Lenroot, R. K, Moul, C., Anderson, V., Frick, P. J. \& Dadds, M. R. (2020). ParentWorks: Evaluation of an online, father-inclusive, universal parenting intervention to reduce child conduct problems. Child Psychiatry E Human Development, 51(4), 503-513. https://doi.org/10.1007/s10578-019-00934-0

Prinz, R. J., Metzler, C. W., Sanders, M. R., Rusby, J. C., \& Cai, C. (2021). Online区 delivered parenting intervention for young children with disruptive behavior problems: a noninferiority trial focused on child and parent outcomes. Journal of Child Psychology and Psychiatry. https://doi.org/10.1111/jcpp.13426

Pusztainé Berényi, K. (2015). Gordon kommunikáció alkalmazási lehetőségei a legkisebbekkel és szüleikkel. [előadás]. IV. BabaArt. Müvészeti napok és szakmai konferencia. 2015. november 9. KMO.

Rackett, P., \& Macdonald, B. (2014). Fun with mum': using video interaction guidance to enhance early relationships and diminish maternal postnatal depression. Educational and Child Psychology, 31(4), 82-92. https://bit.ly/3xqnYss

Reyno, S. M., \& McGrath, P. J. (2006). Predictors of parent training efficacy for child externalizing behavior problems-a meta冈analytic review. Journal of Child Psychology and Psychiatry, 47(1), 99-111. https://doi.org/10.1111/j.14697610.2005.01544.x

Rosenberg, M. B. (2005). Raising Children Compassionately: Parenting the Nonviolent Communication Way. PuddleDancer Press.

Rosenberg, M. B.(2001). A szavak ablakokvagyfalak-Erőszakmentes kommunikáció. Agykontroll $\mathrm{Kft}$.

Sanders, M. R. (2008). Triple P-Positive Parenting Program as a public health approach to strengthening parenting. Journal of Family Psychology, 22(3), 506517. https://doi.org/10.1037/0893-3200.22.3.506

Schore, T. \& Wipfler, P. (2021). Hallgasd meg! - Öt egyszerü eszköz a gyereknevelés mindennapos kihívásaihoz. HVG könyvek.

Shadish, W. R., Ragsdale, K., Glaser, R. R., \& Montgomery, L. M. (1995). The efficacy and effectiveness of marital and family therapy: A perspective from meta囚 analysis. Journal of marital and Family Therapy, 21(4), 345-360. https://doi. org/10.1111/j.1752-0606.1995.tb00170.x

Sörös, I (2016). A Biztos Kezdet Gyerekházak szerepe a társadalmi felzárkóztatásban. [előadás]. A Kora Gyermekkori Nevelés „A szakmai megújítás útjai, lehetősége” Nemzetközi Tudományos Konferencia, 2016. Május 25-26. Debreceni Egyetem Gyermeknevelési és Felnőttképzési Kar.

Suarez, A., Lee, D. Y., Rowe, C., Gomez, A. A., Murowchick, E., \& Linn, P. L. (2014). Freedom project: Nonviolent communication and mindfulness training in prison. Sage Open, 4(1), 1-10. https://doi.org/10.1177/2158244013516154

Szöllősi, K, Odor, A., Kissné Garajszki, Talabér, J., Fogarasi-Grenczer, A., Altorjay, P., Póta, Gy. \& Szabó, L. (2020). The health visitor network in Hungary: a unique 
system in Europe. Turkish Archives of Pediatrics/Türk Pediatri Arşivi, 55(Suppl 1)10. https://doi.org/10.14744/TurkPediatriArs.2020.03271

Tardos A., Kálló É. \& Kovács P. (1983). A baba első lexikonja I-II. Móra.

Taylor, T. K., Webster-Stratton, C., Feil, E. G., Broadbent, B., Widdop, C. S., \& Severson, H. H. (2008). Computer-based intervention with coaching: An example using the Incredible Years program. Cognitive Behaviour Therapy, 37(4), 233246. https://doi.org/10.1080/16506070802364511

Todres, R., \& Bunston, T. (1993). Parent education program evaluation: A review of the literature. Canadian Journal of Community Mental Health, 12(1), 225-257. https://doi.org/10.7870/cjcmh-1993-0013

Vazhappilly, J.J. \& Reyes, M.E.S. (2017). Non-Violent Communication and Marital Relationship: Efficacy of 'Emotion-Focused Couples' Communication Program Among Filipino Couples. Psychological Studies 62, 275-283. https://doi. org/10.1007/s12646-017-0420-z

Az áttekintett laikusoknak szóló gyermeknevelési irodalom ábécé sorrendben (a szakirodalomban szereplőket itt nem szerepeltetjük újra)

Aamodt, S. \& Wang, S. (2012). Üdvözöllek a gyereked agyában - Mi jár a fejében a fogantatástól a diplomáig? 21. Század.

Bronson, P. \& Merryman, A. (2014). Amit rosszul tudtunk a gyermekekről. Kulcslyuk. Byron, T. \& Baveystock, S. (2006). Kicsi angyalkák. Alexandra.

Chua, A. (2011). Battle hymn of the tiger mother. Bloomsbury Publishing PLC.

Cloud, H. \& Townsend, J. (2016). Gyerekhatárok - Mikor mondjunk igent és mikor mondjunk nemet gyermekeinknek? Harmat.

Denkin, E. (2000). Miért nem akkor látsz, amikor jó vagyok? Hogyan neveljünk magabiztos, viselkedni tudó gyereket? 26 alapelv. Alexandra.

Druckerman, P. (2012). Nem harap a spenót. Gyereknevelés francia módra. Libri.

Frost, J. (2010). Szuperdada 2. Amit minden szülö tudni szeretne. Park.

Frost, J. (2011). Szuperdada 1. Hogyan hozzuk ki a legjobbat gyermekeinkböl? Park.

Gerhardt, S. (2009). A szükséges szeretet. Oriold és Társai Kft.

Glaser, U. (2012). Trükkláda szülőknek. Centrál Médiacsoport.

Grosshans, B. A. \& Burton, J. H. (2009). Ki az úr a háznál? Park.

Hayes, E. (2003). A hiszti. Hogyan értsük meg gyermekünk érzelmeit? Alexandra.

Hogg, T. \& Blau, M. (2003). A suttogó titkai I. A csecsemő gondozása és nevelése. Európa.

Hogg, T. \& Blau, M. (2004). A suttogó titkai II. A kisgyermek nevelése. Európa.

Hogg, T. \& Blau, M. (2007). A suttogó mindent megold. Alvásról, evésről, viselkedésről és sok minden másról kezdö és haladó szülőknek. Európa.

Lasbury, J. (2015). Nincs rossz gyerek. Kisgyermekek fegyelmezése megszégyenítés nélkül. Jaffa. 
Latta, N. (2014). Szeress szívvel, nevelj ésszel! 10 aranyszabály, mielőtt az agyadra megy a gyereked. Kulinária.

Mähler, B. \& Musall, P. (2011). Kimerült szülők - Kiút a családi mókuskerékből. Tudatos Lépés kft.

Rogge, J.-U. (2013). Kell a gyereknek a korlát. Park.

Runkel, H. E. (2015). Orditásmentes gyereknevelés. Jaffa.

Siegel, D. \& Payne Bryson, T. (2015). Drámamentes fegyelmezés. A káosz lecsillapítása és a fejlődő gyermeki elme integrált szemléletü gondozása. Ursus Libris.

Süveges, G. (2012). Apaszem. Helikon.

Swanson, N. (2008). Hogyan neveljünk jó gyereket? Útikalauz szülöknek. Athenaeum.

Valliéres, S. (2012). Pszichotrükkök 0-3 éves korig. Libri.

Vida, Á. (2011). Babapszichológia. Lélek, viselkedés, fejlödés 2 éves korig. Kulcslyuk.

Winterhoff, M. (2012). Miért válnak zsarnokká a gyerekeink? - Avagy: a gyermekkor elrablása. Dialóg.

Wyckoff, J. (2017). Fegyelmezés szeretettel. Így kezeld a nyafogást, a hisztit, az evés körüli cirkuszt, a képernyöfüggőséget - és még sok mást! Jaffa. 


\section{Gyöngy, K.}

\section{Possibilities of supporting parents with young children in Hungary and in English-speaking countries worldwide, offline and online - A review of the literature}

Parent support dates back centuries, with various forms ranging from parenting advice to various kinds of parent training. In this literature review, particular emphasis is placed on the support of parents raising young children under the age of three. Different forms of parental support available in Hungary are reviewed; the Hungarian and international solutions to online parent help are then presented in terms of form and effectiveness. At the end of the paper, a relatively new form is presented: the MOOC, that is massive open online courses for parents.

Keywords: parent support, digital self-administered parent training, MOOC

Gyöngy Kinga: https://orcid.org/0000-0001-6416-8548 